\title{
Reconstructing Dewey: Dialectics and Democratic Education
}

\section{Jeff Jackson}

\begin{abstract}
This essay aims to demonstrate the theoretical purchase offered by linking Dewey's educational theory with a rigorous account of dialectical development. Drawing on recent literature which emphasizes the continuing influence of Hegel on Dewey's thought throughout the latter's career, this essay reconstructs Dewey's argument regarding the detrimental effects of "external aims" (e.g., grades, standardized test scores) in education with a specifically Hegelian framework. The goal is to show how emphasizing and drawing out the dialectical character of Dewey's conception of individual experience clarifies his case for why external aims hinder the continuous individual growth that democratic education aims to cultivate.
\end{abstract}

\section{Introduction}

In Freedom and Culture (1939), John Dewey claims that democracy can only truly "serve the world" as long as it is continuously "securing and maintaining an everincreasing release of the powers of human nature" (p. 176). Characteristically, Dewey's educational theory also aims at continuous individual development; his landmark educational work encourages students to grow continuously throughout life, and to avoid simply following a roadmap to the point where learning can stop. In Democracy and Education (1966), he argues in particular that an education which emphasizes the achievement of "external aims" (grades, standardized test scores, etc.) hinders students' capacity for continuous growth, and leads students toward viewing learning as an overly burdensome activity which they should seek to end as quickly as possible. ${ }^{1}$

In addressing the meaning of Deweyan continuous growth, recent scholarship has emphasized Dewey's connection to Hegelian philosophy (a connection 
which is claimed to have lasted beyond his purported break with Hegelianism in the early years of his career). James Good (2006), for instance, describes the conception of individual experience presented throughout Dewey's writings, even in his later works (including Democracy and Education), as essentially an adoption of Hegel's dialectical interaction of subject and object in which both terms "are always changed in and by the process" (p. 144). Taking my cue from this literature, I will reconstruct Dewey's argument against external aims with specifically Hegelian terms, in order to demonstrate how the dialectical conception of experience identified by Good and others can help shed new, important light on Dewey's case against the focus on grades and test scores in education. More specifically, I will argue that making Dewey's case more pointedly dialectical allows us to better understand how an education which depreciates grading will more effectively encourage students to grow through rigorous, difficult experiences than does the typical grade-based education. I will emphasize in particular the distinction Hegel makes in The Phenomenology of Spirit between a being in-itself and a being for-itself as exhibiting two separate ways of engaging with the difficult (or as Hegel would say, "negative") aspects of development. When this Hegelian conception is accentuated in Dewey's educational theory, a robust Deweyan case can be constructed which presents grades and test scores as leading students toward evading rather than engaging with the negative aspect of growth.

My essay will first establish the discursive setting for my argument by discussing the recent work related to Hegel's influence on Dewey's notion of continuous individual growth. I will then move into Dewey's account of how external educational aims hinder students' ability to grow on their own accord throughout life. Toward reconstructing Dewey's argument, I will then provide an in-depth explanation of Hegel's dialectical process of growth, focusing on the importance Hegel places on engagement with negation throughout a being's quest to advance to higher stages of development. I will also make use of the Hegelian and psychoanalytic model of individual development put forward by Eugene Victor Wolfenstein to exhibit how the quest for grades and test scores may diminish a student's desire to endure the challenges of growth in actual situations of self-development during school. Through this reconstruction of Dewey's argument, I hope to demonstrate the value of linking his conception of education for continuous growth with a rigorous account of dialectical development.

\section{Dewey's Hegelian Democracy of Continuous Growth}

Dewey's relationship with Hegel's philosophy was a complex one, and it may appear to have run its course by the time Dewey wrote Democracy and Education. The few times Dewey does explicitly reference Hegel in this text, he does not seek to identify himself with him (e.g., pp. 59-60, p. 95). Also, during the 1890s Dewey did indeed abandon the neo-Hegelian school of thought which was prominent in Great Britain and the United States (headed by T. H. Green, F. H. Bradley, Josiah 
Royce, etc.), and which had heavily influenced him in the early years of his career. Morton White (1943) claims that Dewey in fact decided to "throw Hegel overboard" (p. 151). ${ }^{2}$ However, following Dewey's (1930) own remark that "Hegel has left a permanent deposit in my thinking" (p. 21), Good argues that while Dewey did reject this brand of neo-Hegelianism and its emphasis on a "transcendent absolute," this does not mean he abandoned Hegel himself or the concept of dialectical development (p. 130). Similarly, John Shook (2000) contends that Dewey's break from the neo-Hegelians represented a rejection of the "teleologically final end" sought by absolute idealism, in favor of a focus on active human experience as the only philosophical absolute (p. 154). For Dewey, the neo-Hegelian emphasis on a final stage of all-encompassing consciousness made experience itself not only unimportant, but also hopeless. ${ }^{3}$ This transcendent absolute was impossible to achieve, and so he went about creating (as Good describes) a philosophy of actual "lived experience" which would have relevance to the lives of individuals (2006, p. 178). He sought to focus on the process of living, and "Hegel not only gave Dewey a process philosophy, but the dialectic ... gave him a very rich model of process" (p. 183). Good thus concludes that Dewey's apparent rejection of Hegel "is best viewed as a rejection of the neo-Hegelians' metaphysical reading of Hegel, in favor of a historicist reading in which the absolute is not a transcendent reality. This is consistent with the postulate that in the 1890s Dewey began to take Hegel's Phenomenology of Spirit more seriously than the British neo-Hegelians" (p. 207).

Hence, Shook and Good maintain that Dewey's Hegel emphasizes growth to the greatest possible extent throughout life, rather than the achievement of a single stage of consciousness which has overcome all contradiction. ${ }^{4}$ Larry Hickman (2008) agrees, claiming "Dewey's Hegel was historicist, instrumentalist, and functionalist" (p. 571). Jim Garrison (2006) similarly argues that Dewey's emphasis on the need to respond to continuously expanding experience was inspired by Hegel (p. 5). And Richard Bernstein (2010) points in particular to Hegel's identification of growth as emanating from the inevitable conflicts, or difficulties, of experience as being especially important for Dewey (p. 92). What this recent scholarship claims, then, is that if we focus on what Good calls the "humanist/historicist" (rather than the "metaphysical/theological") Hegel, we can identify the permanent Hegelian influence in Dewey-specifically within Dewey's emphasis on the continuous expansion of individual experience. ${ }^{5}$

Given this concern with continuous individual growth, democracy for Dewey does not refer to any particular institutional arrangement, but rather to the manner in which individuals approach their experiences and grow throughout life. Dewey (1993) contends that "democracy is a personal way of life ... it signifies the possession and continual use of certain attitudes, forming personal character and determining desire and purpose in all the relations of life" (p. 241). Because there is no Platonic notion of a static, eternal reality which only a select few are capable of grasping, a Deweyan democratic society relies on ordinary individuals themselves 
increasing their wisdom through experience. "Reality," for Dewey, is constantly changing, and there is no one with a monopoly on the knowledge of reality, which means that his democracy requires that everyone continuously grow and adapt to changing conditions.

Dewey's conception of education therefore aims at jump-starting this process of continuous growth for individuals at a young age, and his educational writings demonstrate a persistent Hegelian theme of the need to unify apparent "opposites" if this growth is to take place. In "My Pedagogic Creed" (1972), Dewey aims at unifying the journey and goal of education: "education must be conceived as a continuing reconstruction of experience ... the process and the goal of education are one and the same thing" (p. 91). In The School and Society (1900), he writes of unifying the student with other students so that the school "gets a chance to be a miniature community, an embryonic society. This is the fundamental fact, and from this arise continuous and orderly sources of instruction" (p. 32). This type of active cooperation (such as when students learn chemistry through cooking together) encourages students to grow continuously because they are constantly engaging with other students who provide different ideas and perspectives. And in The Child and the Curriculum (1902), Dewey talks of unifying the apparent opposites of the student and the subject matter, so that the child's learning is not made to conform to a fixed curriculum, and the curriculum is not made to reflect merely the child's own interests, but rather so they are linked in a single process where both child and curriculum grow.

Dewey does not focus on the effect of external aims on continuous growth in these works, though he notes in The Child and the Curriculum that the "artificial bribe" of external rewards is used to try to induce learning when the student feels no connection to the subject matter (p. 35). ${ }^{6}$ In Democracy and Education, Dewey expands on the point by claiming that external aims themselves are detrimental to growth. Of course, it is typically believed that without measures like grades or standardized test scores, students will not be motivated to make the effort necessary to learn and grow; Dewey's case is that these measures are actually unnecessary, and, worse, produce a type of counterfeit growth. My claim will be that seeing Dewey in his full Hegelian light helps illuminate his argument against external aims, and thus strengthens his case for why external aims hinder rather than aid students' development.

\section{External Aims and Continuous Growth}

In Democracy and Education, Dewey argues that education must value the process of growth over any particular endpoint. This means "(i) that the educational process has no end beyond itself; it is its own end; and that (ii) the educational process is one of continual reorganizing, reconstructing, transforming” (p. 50). Hence, a truly democratic education aids students in viewing all of life as an opportunity for continuing growth and change: "The criterion of the value of school education 
is the extent in which it creates a desire for continued growth and supplies means for making the desire effective in fact" (p. 53).

So why would external aims hinder rather than encourage continuous growth? Within an education focused on grades and standardized test scores, Dewey sees the process of growing itself not as its own end, but as the means toward an end that is imposed on students. When students study impractical subject matter, with the apparent aim of preparing themselves to achieve well-paying careers, their activities are a mere means to an end; and furthermore, this end (landing a job in capitalist society) is well beyond what they can accomplish with their present activities. Thus, Dewey sees other, more immediate external goods being used to motivate students to work: "Since the end of growth is outside of and beyond the process of growing, external agents have to be resorted to to induce movement toward it" (p. 51). Grades and test scores are our main external agents, and the student comes to see work as only having value if it brings those rewards. Essentially, the process of working itself is made unimportant next to the external end which is to be attained. The activity has little intrinsic value and is instead merely something to get through in order to reach the endpoint: "In contrast with fulfilling some process in order that activity may go on, stands the static character of an end which is imposed from without the activity. It is always conceived of as fixed; it is something to be attained and possessed. When one has such a notion, activity is a mere unavoidable means to something else; it is not significant or important on its own account" (pp. 105106). This makes school activity itself not only unimportant, but rather miserable, for "every divorce of end from means diminishes by that much the significance of the activity and tends to reduce it to a drudgery from which one would escape if he could" (p. 106). Students find little satisfaction in working, and come to rely entirely on a good grade to make this process worthwhile. Rather than taking pleasure in the ongoing process of work, students seek to end this process as quickly as possible in order to seek pleasure in the process having ended, in a lack of activity.

Dewey's case, then, is that external aims devalue the process of growing, since work is not engaged in for the growing experience but more for finishing it quickly to reach a static endpoint external to the activity itself. Typical educational settings thus work against democracy by educating students not to see growth as inherently valuable and ongoing, but as something to get through rapidly. As Dewey puts it, "until the democratic criterion of the intrinsic significance of every growing experience is recognized, we shall be intellectually confused by the demand for adaptation to external aims" (p. 109).

I contend that Dewey's analysis reflects a great deal of student behavior, but is also unclear regarding how exactly a lack of external aims would encourage students to show discipline when confronted with difficult obstacles. The rest of my essay will focus on reconstructing this growing experience and how it is impacted by external aims. As noted earlier, Good claims that Dewey's conception of individual experience remained an adoption of Hegel's dialectical interaction of subject and 
object. And indeed, this dialectical quality to experience is evident in Democracy and Education; Dewey asserts that "what even an infant 'experiences' is not a passively received quality impressed by an object, but the effect which some activity of handling, throwing, pounding, tearing, etc., has upon an object, and the consequent effect of the object upon the direction of activities" (pp. 270-271). Subject and object interact with each other, in dialectical fashion, and each one is changed while changing the other within an activity. What an individual learns, therefore, is the way both the self and the objects of the self's experience are altered by the activity (p. 272). Hence, in order to continuously learn, the student must actively engage with the objects of her experience and constantly seek out new objects to interact with and learn from. The school's role is to encourage this active engagement, allowing students new situations and new problems to deal with so that they always have new opportunities for growth (p. 274).

This description of experience clearly has a dialectical core, and I argue that drawing out the Hegel in Dewey's analysis, and thus making it even more explicitly dialectical, can clarify and strengthen Dewey's case against external aims. In his 1897 Lecture on Hegel, Dewey credits Hegel with "the idea that the side of opposition, of apparent discord, and even of contradiction, was the moving spring by which the positive first really made itself positive" (p. 106). ${ }^{7}$ Hegel's dialectical process of growth does indeed emphasize an intrinsic connection between an individual and the objects of experience which oppose, or negate, her. In fact, Hegel's analysis implies that the negative is the self-it is as much the self as the self itself is. And I will argue that this particular unification of opposites, this notion of an individual seeing herself in difficulty, can help us make a robust Deweyan case for why a student can more effectively grow through difficulty when she has been educated without grades.

Earlier, it was noted by Good that Dewey's nonmetaphysical reading of Hegel was reflected in a greater interest in The Phenomenology of Spirit than was shown by the neo-Hegelians. Good explains that the Phenomenology shows "the development of an open and intelligent mind in a complex society that lacks universally accepted values as the main character encounters a wide variety of experiences" (p. 25). The "process" aspect of the dialectic is emphasized rather than any transcendent absolute, making the Phenomenology appropriate for exhibiting the value of dialectical development in Dewey's educational theory.

\section{Individual Growth in the Hegelian Dialectic}

As just intimated, The Phenomenology of Spirit (1977) is itself an educational experience, that is, the experience of consciousness undergoing development. In the introduction, Hegel describes how the book presents "the series of configurations which consciousness goes through ... the detailed history of the education of consciousness itself" (p. 50). The book thus follows the path of consciousness enduring the dialectical progression toward higher developmental stages. This section, 
however, will not simply provide an exposition of this progression, but will engage the relevant elements of Hegel's dialectic for our discussion of Deweyan educational development.

In the Phenomenology, Hegel provides an explication of the content of experience itself, illustrating a dialectical process in which an advancing being achieves advancement by encountering its opposite-its contradiction-and overcoming this "other to itself" by bringing this other into itself. He states that "experience is the name we give to just this movement, in which the immediate, the unexperienced, i.e., the abstract ... becomes alienated from itself and then returns to itself from this alienation, and is only then revealed for the first time in its actuality and truth" (p. 21). This is the way a being grows past its initial simplicity; by engaging with and overcoming its other, its obstacle, it returns to itself now in more advanced form: "since the essence of the individual shape-universal Life-and what exists for itself is in itself simple substance, when this substance places the other within itself it supersedes this its simplicity or its essence, i.e., it divides it, and this dividedness of the differenceless fluid medium is just what establishes individuality" (p. 108). Development is thus just this process where a being divides itself and then reunites with itself having grown through its encounter with its opposite. And for Hegel, there can be no life which is not characterized by these encounters with otherness.

Moving from the more general term of "being" to the individual, the depiction of advancement that Hegel draws provides a framework for conceptualizing individual growth. Individuals generate opposition to themselves simply by trying to advance; they achieve advancement by bringing that opposition into themselves-by overcoming the opposition. When an individual tries to advance in any realm-whether she is attempting to make leaps as a math student, or to compete at higher and higher levels in athletics, or to navigate social relationships more successfully-there will constantly be obstacles in the individual's way toward achieving the desired progress, and she may have to deal with being defeated by an obstacle before learning how to overcome it. An individual cannot expect to progress without experiencing these moments of contradiction along the way. When individuals remain inert, they are seeking to avoid these "becoming-others"; it is impossible, however, to exist without obstacles, and those trying to remain this way will likely be frightened by the obstacles that do come, and will seek to protect themselves rather than take on these challenges (more on this in the next section). Most importantly, an individual who understands the value of the experience of dealing with these obstacles, these "negative moments" of development, is ready to see (as Dewey puts it) the "intrinsic significance of every growing experience," even when the going gets extremely tough. As Hegel says, "[the life of Spirit] is this power, not as something positive, which closes its eyes to the negative, as when we say of something that it is nothing or is false, and then, having done with it, turn away and pass on to something else; on the contrary, Spirit is this power only by looking the negative in the face, and tarrying with it. This tarrying with the nega- 
tive is the magical power that converts it into being" (p. 19). The tough moment is not a false moment in the process or a moment to be avoided, but one that is integral to individual development.

It follows, then, that when an individual attempts to grow, there will undoubtedly be moments, whether in the school realm or any other, where the individual will not know what to do, will not know how to handle an obstacle, and will likely suffer a defeat. This is part of the growing experience, though, and the individual should not seek to avoid it. Hegel describes this as a moment of disparity, explaining that "the disparity which exists in consciousness between the 'I' and the substance which is its object is the distinction between them, the negative in general" (p. 21). Ultimately, what is most critical for the developing individual is that she sees the moment of disparity and the possible defeat that will result from it as not representing the end of the world. Missteps are taken, but these missteps often provide invaluable knowledge which could not be attained otherwise. It is true that "to know something falsely means that there is a disparity between knowledge and its Substance. But this very disparity is the process of distinguishing in general, which is an essential moment [in knowing]" (p. 23). Put simply, it is okay to know something falsely at the moment, because this is a vital part of the process of forming connections between "subject" and "predicate"-between the individual and the objects of experience which belong to her. It is not enough, though, merely to recognize that something is false or that something does not work, and to try something else that hopefully will work. Hegel contends that recognizing "that something is not the case, is a merely negative insight, a dead end which does not lead to a new content beyond itself ... this insight is the negative that fails to see the positive within itself" (p. 36). Seeing the positive within the negative moment allows an individual to grow more effectively; the negative is not thrown away, but fully felt and understood so that the lessons of this "contradiction" can be wholly appreciated. The individual must experience and study the negative moment, and if so then she will more likely construct a path which can lead to advancement, instead of randomly trying this or that in the hope that the new action will bring the desired result. Thus, the path of advancement is one in which "the negative belongs to the content itself, and is the positive, both as the immanent movement and determination of the content, and as the whole of this process" (p. 36).

The key differentiation which Hegel leads us to here is the one between a being in-itself and a being for-itself. The being in-itself cannot recognize itself in its opposite; the "other" is for this being only an external entity. Conversely, the being for-itself engages with this other and sees in it the reflection of itself. By merging itself into the other, this being can see itself in what is opposite to itself, and hence its own being exists for-itself by seeing itself in what is other to itself. Hegel describes how for the being in-itself "life is indeed one of untroubled equality and unity with itself, for which otherness and alienation, and the overcoming of alienation, are not serious matters. But this in-itself is abstract universality, in which the nature of the 
divine life to be for itself, and so too the self-movement of the form, are altogether left out of account" (p. 10). A being for-itself, therefore, engages with and sees herself in alienating experiences. Within the discussion of educating individuals to engage fully with the "negative moment" of development, the implications of the differentiation between a being in-itself and a being for-itself are significant. Undoubtedly, the individual who sees herself in the obstacle to growth she is confronted with, rather than seeing it as an external entity to avoid if possible, will more likely view the negative moment as an essential aspect of development, fully experience and draw the lessons from this moment, and ultimately overcome it. Paulo Freire (1970) in fact relies on this very distinction in his discussion of the education of oppressed peoples: "the oppressed only begin to develop when, surmounting the contradiction in which they are caught, they become 'beings for themselves"' (p. 161). Education, then, must help individuals develop into true "beings for themselves," and this is done by allowing them to recognize themselves in their opposites, to view their obstacles as generated out of their own development. Seeing themselves in those obstacles, they are more likely to achieve a victory over such challenges.

As we conclude the discussion of Hegel, it is crucial to recognize that he provides a notion of life where an individual is only whole while in the process of growing. This is his connection between the "realm of being" (stability and constancy) and the "realm of becoming" (perpetual change and transformation), for we are only whole beings when we are actively engaging with becoming-others. His assertion is that "the living Substance is being which is in truth Subject, or, what is the same, is in truth actual only in so far as it is the movement of positing itself, or is the mediation of its self-othering with itself" (p. 10). For Hegel, being is not true being without the experience of becoming-others, and the overcoming of these others. By cultivating among students the power to actively engage with the inherent obstacles of experience, schools can develop individuals who understand the "intrinsic significance of every growing experience" and seek to "learn in the process of living," rather than learning so that learning can end. When we thus approach Dewey's target of educating students for democracy-for continuous growth in response to the changing circumstances we live in-Hegel's process in which being equals becoming leads us to consider how students can be encouraged to see themselves in negation-to be "beings for themselves."

\section{Grades and Dialectical Development}

The discussion of Hegel may leave us feeling caught in the abstract, and so we must be more concrete in order to reconstruct a Deweyan argument for why an education lacking external aims could more effectively cultivate engagement with the obstacles of growth. To do this, I will use the model of individual development put forward by Eugene Victor Wolfenstein in his text, Psychoanalytic-Marxism: Groundwork (1993), a model which is both Hegelian and psychoanalytic in its orientation. One factor which must be recognized about students when they confront the moment of 
disparity - and are unsure how to handle an obstacle - is that they surely feel significant uncertainty regarding the outcome of their struggle. And Dewey (1966) notes that when students have an external aim imposed on their activities, they tend to have a "lack of interest in the novel, aversion to progress, and dread of the uncertain and the unknown" (p. 51). Wolfenstein's dialectical model deals concretely with the individual's response to the uncertainty inherent in growth, and helps clarify why students in pursuit of grades often dread uncertainty rather than engage with it.

Wolfenstein seeks to establish the principles of the healthy dialectical development of an individual, with his model centering on a child's early experiences of anxiety and how the child learns to deal with those anxious situations. He establishes, as a general matter, that "anxiety attaches to any situation involving a significant level of uncertainty" (p. 240). Again, the uncertain aspect is critical for this discussion, with any attempt at individual progress bringing some level of uncertainty due to the fact that we cannot know at the start if we will succeed. When the uncertainty is powerful enough, it will create anxiety in the individual; and at times, the uncertainty cannot be prevented from begetting anxiety, especially when the individual encounters a type of uncertainty she has never faced before. A critical factor is how a child develops a response to anxiety, for if the child learns to tolerate anxiety (i.e., accept that it is there and resolve to work through it), then she can more intelligently observe the situation and choose a course of action, rather than rely on an instinctual "flight-fight" response (p. 241). The situation may change from one which controls a child to one which the child can control, and she will then more likely progress through uncertainty instead of seeking to escape from it in the quickest, easiest way possible.

I will now apply these ideas to the student experience of working in the classroom. Dewey (1966) describes work thusly: "Like play, it signifies purposeful activity and differs not in that activity is subordinated to an external result, but in the fact that a longer course of activity is occasioned by the idea of a result. The demand for continuous attention is greater, and more intelligence must be shown in selecting and shaping means" (p. 204). Work requires discipline toward accomplishing a goal, and unlike play, cannot be fully satisfying without that accomplishment (this goal, though, is internal to the activity, such as learning a math concept, rather than external in the sense of grades or money). And if students are to actively engage with work, to seek out activity which is challenging to them, then they must be able to find pleasure in the process toward that internal accomplishment. Wolfenstein connects the pleasure possible through work to "the pleasure that accompanies the surmounting of a difficulty-pleasure in achievement or mastery. When this pleasure is sufficiently intense, the distinction between work and play is virtually eliminated" (p. 234). Accomplishment in work can be expected to entail at least some difficulty. To achieve her aims, an individual must engage with that difficulty and overcome it. And, when she does not run away from difficulty but rather takes it on and enjoys overcoming it, the experience of work is itself pleasurable and becomes similar to play. 
Let us take a situation in which students are in a classroom working with the teacher on a math concept. On its own, this setting allows for an effective dialectical experience of work. There will be frustrations along the way for these students, as the concept being studied is difficult and does not immediately become clear to them. These frustrations represent the moment of disparity, when there is a gap between the individual and the level of mathematical ability she strives to attain. But through their work, these students (with the teacher's aid) can overcome their frustrations, with the teacher's and students' efforts coming together to free the students of their confusion and allow them to "return to themselves" as more highly intellectual beings. An important point is that the moment when the students say "Aha!" and finally get it can and should be a pleasurable moment, demonstrating the pleasure in achievement or mastery. And within the classroom situation presented here, the students should not fear the uncertainty that emerges when they are confused by the math concept; they can see the uncertainty as a resistance generated out of their own development toward becoming a more advanced math student. Rather than viewing uncertainty as a state to avoid, they can see themselves in the uncertainty, thus demonstrating themselves as true "beings for themselves."

As noted in the discussion of Hegel, individuals must see the positive within the negative moment of development if they are truly to advance. By fully understanding the confusion they felt when figuring out the math concept, as well as understanding how they overcame that confusion, the students can prepare themselves for the inevitable uncertainty they will confront at future stages of development, meaning they can develop strong feelings of control over uncertainty. Dewey captures this idea with his definition of education: "It is that reconstruction or reorganization of experience which adds to the meaning of experience, and which increases ability to direct the course of subsequent experience" (1966, p. 76). When unique, unforeseen challenges come along in doing work, students who develop dialectically in this way are more likely to feel in control of the uncertainty, to feel confident in their ability to overcome difficulty, and to look forward to the pleasure of overcoming that difficulty, meaning they will be prepared for continuous, democratic growth. They will have become better through practice at tolerating and working through anxiety because of repeated experiences of overcoming in school, therefore making the uncertainty of work less likely to cause anxiety-the object of experience (the difficulty of work) will have thus been changed by the subject. Students will more likely want to work and take on challenges when they have been educated this way, instead of searching for a state of no work and no challenges. As they go on in life, they will more likely seek, as Russell Muirhead (2004) describes them, the "internal goods" of work, which include "habits of the mind, heart, and body that are instilled through participating in certain activities," rather than the less meaningful "external goods such as money, status, and power" (p. 87). These internal goods are what only work can offer, and they differ from the external goods in that "they can be gained only through engagement in an activity. They cannot be 
borrowed or purchased, nor can their value be realized by merely simulating them" (p. 87). Individuals who work for internal goods engage in the activity because of what it offers them as an expression of their individualities, and do that work for as long as they possibly can. They do not merely hope their work will quickly bring them enough money so they can stop working and live "undemocratically" for the rest of their lives in a state of inertia. These individuals feel they are only true beings while in the process of becoming.

Above all, reaping the pleasure of overcoming difficulty requires engagement with the moment of uncertainty and the anxiety that this moment may cause. Evasion is merely an attempt to remain in the fetal position and avoid any action to take control. Wolfenstein describes how "a defense is an avoidance of anxiety in a situation where tolerance of anxiety is necessary for the preservation or the securing of pleasure" (p. 242). In many cases, if we fail to first tolerate anxiety we will only remove the possibility of true pleasure, and will seek to evade situations which cause uncertainty. Hence, if an education system is to develop students who can experience the pleasure of working (and thus approach work actively without need of external manipulation), it will not overwhelm students with the consequences of failure within the negative moment of work, but instead will focus on cultivating engagement with that moment, and will not distract from that focus.

However, within typical educational settings there seems to be not only great distraction from that focus, but the proper engagement with resistances rather appears to be itself a distraction from an intense spotlight on grade fetishism. The students may still reap pleasure from grasping that math concept, but it is often fleeting due to their awareness that this learning is not the primary purpose of this routine. After the lesson, all the students may have a solid understanding of the math concept and be ready to grow further, but the educational process does not turn on this point. The teacher must still design a test which can effectively sort the students into groups of A, B, C, D, and F. The process of growth is essentially forgotten, for the school takes note only of the external good cut off from the process. As Hegel says, "the bare result is the corpse which has left the guiding tendency behind it" (p. 3).

Still, one could argue that achieving a good grade does represent a dialectical process. This only appears to contradict the argument we have been building, though. A dialectic which is not actually conducive to the tolerance of anxiety, and which takes focus away from the overcoming of difficulty, is what Wolfenstein calls a pseudodialectic (p. 242). It may appear that accomplishing a good grade requires overcoming the resistances within work, but often the grade takes the students' focus away from overcoming, and makes it so that achieving a good grade by cheating or taking the easiest path to apparent achievement is often more desirable than doing all the work. This is because the actual work process has become largely irrelevant as anxiety can only be overcome when a good grade has been attained. Thus, all of work is now the negative moment of this pseudodialectic, and the "overcoming" aspect lies in receiving the external aim. Furthermore, the negative moment within 
the healthy work dialectic described above now becomes treacherous for a student, because it serves as a signal that the good grade (on which everything depends) may not be reached; those moments when the students do not grasp the math concept produce images in their minds of bad grades, scorn from their teacher, and anger from their parents. They must break free of these moments and end the anxiety, but this is too infrequently done by tolerating the anxiety of work itself. Instead, students often search for the quickest, easiest path toward the good grade, with little interest in enduring the dialectical process of work with all its resistances and overcoming of resistances. There is little room for the pleasure in achievement or mastery, for the accomplishment of work is now part of the negative moment of this pseudodialectic just like all the rest of work. The external good is all that can make this process worthwhile, and so the work simply must be done as quickly and easily as possible. Hence, the students come to fear the uncertainty inherent in doing work, thus stunting their democratic development by keeping them as "beings in themselves."

My goal has been to show how Dewey's argument regarding the detrimental effects of external aims on continuous growth can be clarified through a more rigorous grounding in Hegelian dialectics. Specifically, if the focus of Dewey's analysis is placed on the ruptured connection between an individual and new objects of experience, and thus the creation of a dualism between the individual and the negative moment of growth, then Dewey's case against external aims becomes more fully elucidated. This has been the purpose of my reconstruction of Dewey's argument.

\section{Conclusion}

I have aimed to demonstrate why Dewey's educational theory benefits substantially from a firm link with the Hegelian dialectical process. Starting with Dewey's claim that external aims such as grades and standardized test scores hinder, rather than promote, continuous individual growth, I have used the Hegelian distinction between in-itself and for-itself to show how external aims can encourage students to defend themselves from difficult objects of experience. Thus, within typical educational settings, students are led toward seeking the easiest possible growth process. Obstacles are inherent to any growing experience, though, and so Dewey's democratic education requires that students be developed as "beings for themselves"individuals who see themselves in the challenges presented by growth. Regarding external aims, then, a rigorous engagement with Hegelian dialectics creates a clear explanation of the problem and a clear prescription: the focus on external aims leads students toward fearing difficulty in school, and so the school must encourage students to thoroughly engage with this difficulty and fully experience the pleasure of mastering difficulty-without the threat of a substandard grade looming to devalue their educational record. If we are to make Deweyan growth in the classroom "a more practical pedagogical ideal," I believe this analysis should be taken into account. 
It should also be noted that my analysis does not imply that Hegel was the sole influence on Dewey's notion of continuous growth. Naoko Saito (2005) emphasizes Ralph Waldo Emerson's influence, as does Richard Rorty (1999), and Dewey did indeed refer to Emerson as the "philosopher of democracy" (1977b). Both Saito and Rorty also highlight the influence of Darwin, while Andrew Reck (1984) and D.C. Phillips (1971) stress the influence of William James. Emerson, Darwin, and James all had notions of continuous growth, and I do not suggest that Dewey's thought was untouched by these thinkers. But if we grant the "permanent Hegelian deposit," then we can use the dialectical conception of experience identified by Good, Garrison, and others to understand better the role of "negative" moments in putting Deweyan growth into practice, and how external aims may affect students' willingness to engage with such moments.

Dewey (1939) declares about democracy that "the cause of democratic freedom is the cause of the fullest possible realization of human potentialities" (p. 129). With our understanding of how external aims stunt such realization, we may better illustrate why the domination of the classroom by external aims may need to cease, in order that students can fully experience the pleasure of learning which often seems nonexistent while they are chasing grades and high test scores. This would amount to a more dialectical education, which makes the overcoming of "otherness" into the focus of schooling, rather than a wholly unpleasant distraction along the way toward meeting fixed standards. In this way, achieving a more democratic education requires achieving a more dialectical education.

\section{Acknowledgments}

My thanks to Shane Ralston and two anonymous reviewers for their extremely helpful comments; and to the late Victor Wolfenstein, to whom I owe more than I can possibly express.

\section{Notes}

1. For a valuable account of the use of external aims (particularly standardized testing) during Dewey's time, see Mark Garrison (2009).

2. For similar views, see Andrew Reck (1984) and D.C. Phillips (1971).

3. For elaboration on this point, see Human Nature and Conduct (1922, pp. 288-289)

4. For the neo-Hegelian view, see Josiah Royce (1900), T. H. Green (1906), and F. H. Bradley (1914).

5. David Waddington (2010) also provides valuable analysis of the Dewey-Hegel connection, though he focuses on the synthesis of personal and social interests in The Philosophy of Right, rather than the continuous expansion of experience in The Phenomenology of Spirit, which will be my focus.

6. There is also a discussion of external aims in "Education, Direct and Indirect" (1977a).

7. Printed in John Shook and James Good (2010).

8. This phrase is from Shane Ralston (2011); important recent attempts to make Deweyan growth more practical include Naoko Saito (2005), Stephen Fishman and Lucille McCarthy (2007), and James Johnston (2009). 


\section{References}

Bernstein, R. (2010). The pragmatic turn. Cambridge: Polity Press.

Bradley, F. H. (1914). Essays on truth and reality. Oxford: Clarendon Press.

Dewey, J. (1900). The school and society. Chicago: University of Chicago Press.

Dewey, J. (1902). The child and the curriculum. Chicago: University of Chicago Press.

Dewey, J. (1922). Human nature and conduct. New York: Henry Holt.

Dewey, J. (1930). From absolutism to experimentalism. In George Adams \& Wm.

Pepperell Montague (Eds.), Contemporary american philosophy, vol. 2 (pp. 13-

27): New York: Macmillan.

Dewey, J. (1939). Freedom and culture. New York: Putnam.

Dewey, J. (1966). Democracy and education. New York: The Free Press. (Original work published 1916).

Dewey, J. (1972). My pedagogic creed. In Jo Ann Boydston (Ed.), John Dewey: The early works, 1882-1898, vol. 5 (pp. 84-95). Carbondale: Southern Illinois University Press. (Original work published 1897).

Dewey, J. (1977a). Education, direct and indirect. In Jo Ann Boydston (Ed.), John

Dewey: The middle works, 1899-1924, vol. 3 (pp. 240-248). Carbondale: Southern Illinois University Press. (Original work published 1909).

Dewey, J. (1977b). Emerson-the philosopher of democracy. In Jo Ann Boydston (Ed.), John Dewey: The middle works, 1899-1924, vol. 3 (pp. 184-192). Carbondale: Southern Illinois University Press. (Original work published 1903).

Dewey, J. (1993). Creative democracy—the task before us. In Debra Morris and Ian Shapiro (Eds.), John Dewey: The political writings (pp. 240-245). Indianapolis: Hackett. (Original work published 1939).

Fishman, S., \& McCarthy, L. (2007). John Dewey and the philosophy and practice of hope. Urbana: University of Illinois Press.

Freire, P. (1970). Pedagogy of the oppressed. New York: Continuum International. Garrison, J. (2006). The "permanent deposit" of Hegelian thought in Dewey's theory of inquiry. Educational Theory, 56(1), pp. 1-37.

Garrison, M. (2009). A measure of failure: The political origins of standardized testing. Albany: State University of New York Press.

Good, J. (2006). A search for unity in diversity: The "permanent Hegelian deposit" in the philosophy of John Dewey. Lanham, MD: Lexington Books.

Green, T. H. (1906). Prolegomena to ethics. Oxford: Clarendon.

Hegel, G. W. F. (1977). The Phenomenology of spirit. New York: Oxford University Press. (Original work published 1807).

Hickman, L. (2008). Dewey's Hegel: A search for unity in diversity, or diversity as the growth of unity? Transactions of the Charles S. Peirce Society, 44(4), pp. 569-576. Johnston, J. (2009). Deweyan inquiry: From education theory to practice. Albany: State University of New York Press.

Muirhead, R. (2004). Just work. Cambridge: Harvard University Press. 
Phillips, D. C. (1971). James, Dewey, and the reflex arc. Journal of the History of Ideas, 32(4), pp. 555-568.

Ralston, S. (2011). A more practical pedagogical ideal: Searching for a criterion of Deweyan growth. Educational Theory, 61(3), pp. 351-364.

Reck, A. (1984). The influence of William James on John Dewey in psychology. Transactions of the Charles S. Peirce Society, 20(2), pp. 87-117.

Rorty, R. (1999). Philosophy and social hope. New York: Penguin.

Royce, J. (1900). The religious aspect of philosophy. Boston: Houghton Mifflin.

Saito, N. (2005). The gleam of light: Moral perfectionism and education in Dewey and Emerson. New York: Fordham University Press.

Shook, J. (2000). Dewey's empirical theory of knowledge and reality. Nashville: Vanderbilt University Press.

Shook, J., \& Good, J. (2010). John Dewey's philosophy of spirit, with the 1897 lecture on Hegel. New York: Fordham University Press.

Waddington, D. (2010). Uncovering Hegelian connections: A new look at Dewey's early educational ideas. Education and Culture, 26(1), pp. 67-81.

White, M. (1943). The origin of Dewey's instrumentalism. New York: Columbia University Press.

Wolfenstein, E.V. (1993). Psychoanalytic-Marxism: Groundwork. New York: The Guilford Press.

Jeff Jackson is a graduate student in Political Science at UCLA.

E-mail: jjack32@ucla.edu 